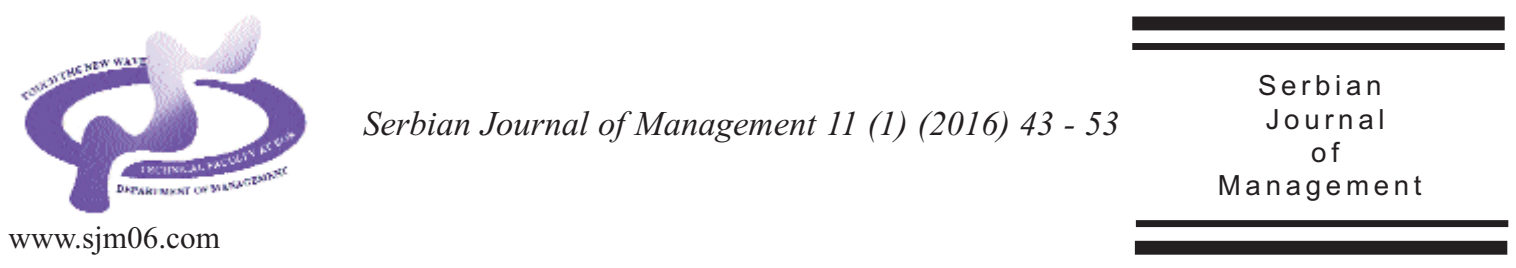

\title{
RANKING OF COMPANIES ACCORDING TO THE INDICATORS OF CORPORATE SOCIAL RESPONSIBILITY BASED ON SWARA AND ARAS METHODS
}

\author{
Darjan Karabasevic*, Jane Paunkovic and Dragisa Stanujkic \\ Faculty of Management Zajecar, Megatrend University, \\ Park suma "Kraljevica" bb, 19000 Zajecar, Serbia
}

(Received 6 March 2015; accepted 1 June 2015)

\begin{abstract}
Corporate sector and companies have recognized the importance of implementation of strategy of corporate social responsibility in order to increase the company's image and responsibility towards society and the communities where they operate. Multinational companies in their everyday activities and operations pay more attention to sustainable models of corporate social responsibility. The focus of this paper is to identify the indicators of corporate social responsibility and to rank companies according to the indicators. Proposed framework for evaluation and ranking is based on the SWARA and the ARAS methods. The usability and efficiency of the proposed framework is shown on an illustrative example.
\end{abstract}

Keywords: corporate social responsibility, CSR indicators, CSR dimensions, SWARA, ARAS, MCDM

\section{INTRODUCTION}

In contemporary business, companies are not only recognized for its business results and the position they occupy on the market, but also by their characteristics in terms of responsibility towards the community, and support for the employees and business partners, care for the environment and sustainable development.

The concept of corporate sustainability derives from the general concept of sustainable development, in relation to organizations. The Earth Summit in Rio de Janeiro in 1992 initiated general acceptance of sustainable development by business

\footnotetext{
* Corresponding author: darjankarabasevic@gmail.com DOI:10.5937/sjm11-7877
} 
leaders, politicians and NGOs (Dyllick \& Hockerts, 2002).

For organizations, it was a challenge to simultaneously improve social and human welfare while reducing ecological impact and ensuring the effective achievement of organizational objectives (Sharma \& Ruud, 2003). Environmental protection (Shrivastava, 1995) or social responsibility of an organization (Carroll, 1999) may be the main focus of corporation's sustainability, but it also may expanded to integrate corporate economic activities with organizational concern about the natural and the social environment (Dyllick \& Hockerts, 2002). Corporate social responsibility is also used to describe the integration of social, environmental, and economic concerns into an organization's culture, decision-making, strategy, and operations (Berger et al., 2007).

Corporate social responsibility is becoming increasingly important parameter in evaluation of the company. Inadequate rating in terms of social responsibility can affect the image of the company, and ultimately may affect the operating results of the company. If the company is socially responsible and nurtures a positive image, it means that the company cares about quality relationships to employees, partners, communities and the natural environment. So that social responsibility becomes the basis for sustainable development of business of each company.

Commission of the European Communities (2002) defines CSR as a concept in which companies integrate in its business concern for society and the natural environment and in interaction with stakeholders, on a voluntary basis. The European Union outlined that the European market should be built on "balanced economic growth and price stability, a highly competitive social market economy, aiming at full employment and social progress, and a high level of protection and improvement of the quality of the environment" (EU Treaty of Lisbon art. 3, 2007).

In the European Union, environment action programs - EAP, have directed the development of EU environment policy last 40 years. The Sixth Environmental Action Program (European Comission, 2010) which was in action from 2002 to 2012, focused on four priority areas, climate change, biodiversity, environment and health, and sustainable management of resources and wastes. The Sixth EAP accentuated that high environmental standards are also an engine for innovation and business opportunities, and must work to de-couple environmental impacts and degradation from economic growth: "Business must operate in a more eco-efficient way, in other words producing the same or more products with less input and less waste, and consumption patterns have to become more sustainable" (Paunkovic, 2014).

Investigating the definitions of topics in corporate social responsibility from certain literature we have noted three basic dimensions of CSR: social dimension of CSR involves operation of CSR towards society and community to contribute to a better society by being aware of its impact of operations on the community; the economic dimension of action includes that company through CSR operations improve positive image that may have impact ultimately on profitability; dimension of the natural environment (operation of CSR aims that company operations take place in the natural environment and develop in a sustainable way). In addition to operating results and financial indicators, the company with CSR activities presents itself as socially 
responsible business by giving strong support to employees, environment and society (Kotler \& Lee, 2005; Dahlsrud, 2006; Waldman et al., 2006; Uddin et al., 2008; RobecoSAM AG, 2014).

Multiple Criteria Decision-Making (MCDM) methods have been used in a number of research papers measuring the performance of companies in terms of corporate social responsibility using CSR indicators. Ebrahimi et al. (2014) uses MCDM for assessing CSR by applying Shannon entropy and VIKOR methods. Chen and Fan (2011) use fuzzy ANP to measure CSR, and Tafti et al. (2012) also uses fuzzy ANP for the assessment of CSR according to Islamic values.

This paper proposes a framework for ranking companies according to the indicators of CSR, with an illustrative example in which three companies will be ranked according to their activities in terms of CSR according to the indicators based on the use of SWARA and ARAS methods.

In the proposed approach the SWARA method is applied for determining weights of CSR indicators and ARAS method is applied for determining CSR of evaluated alternatives.

One of main objectives of the proposed framework is to make it simple and easy to use, which had a great influence to the MCDM method used in the proposed framework. As shown in Stanujkic et al. (2015), the use of the SWARA method requires significantly lower number of pairwise comparisons compared to the use of AHP method and the computational procedure of the SWARA method is also simpler compared to computational procedure of the AHP method. Similarity can be specified for the ARAS method which computational procedure is simpler compared to computational procedures of some prominent MCDM methods such as TOPSIS (Hwang \& Yoon, 1981), VIKOR (Opricovic, 1998 ), PROMETHEE (Brans \& Vinkce, 1985) and so on. Finally, to maintain simplicity, in the proposed framework is intentionaly avoided the use of fuzzy numbers, as wel as the use of fuzzy extensions of above mentioned MCDM methods.

Therefore, this manuscript is organized as follows: in section 2 CSR indicators that will be relevant for further research are defined, then in section 3 SWARA method is introduced, in section 4 ARAS method is presented. To further scrutinize the process of ranking companies according to indicators of CSR in section 5 a framework for ranking companies according to the CSR indicators is presented, while in section 6 illustrative example is presented.

\section{IDENTIFICATION OF CSR INDICATORS}

Indicators of CSR represent a certain set of indicators, based on which, an objective assessment of the implementation of CSR in the company or organization is performed, and to what extent the CSR is applied in practice.

Companies are investing significant resources into finding the "ideal" set of indicators of CSR. However, there is no consensus in the literature which determines the weight of indicators of CSR, and it may vary from author to author. In general, there is an agreement between the dimensions of action in three spheres. Graves labels dimensions of action as „3 $\mathrm{P}$ “: for Profit: economic dimension, People: social dimension and Planet for ecological 
dimension or environment dimension (Graves et al., 2002).

Some of the studies deal with the measurement of CSR and ranking of companies according to the CSR as well as indicators of CSR (Turker, 2009; Pérez \& Bosque, 2013; Ebrahimi et al., 2014; Farooq et al., 2014).

Certain number of studies have approached the problem of defining the weights of CSR as follows: Krut and Munis (1998) in their study of performance measurement of CSR do not use weights, Graves et al. (2002) in their research give the same weight to each of the criteria, $\mathrm{Hu}$ et al. (2011) uses the principle of assigning different weights with Fuzzy MCDM method, MCDM VIKOR method is used in his research by Ebrahimi et al. (2014), but weight is determined by Shannon's entropy while for the ranking of alternatives and the companies applies VIKOR method, while Graafland et al. (2004) for assigning weights are using weights based on the responses of companies and NGOs.

The study included three mobile telecommunication companies (Telekom Srbija d.o.o. designated as $A_{1}$, Telenor d.o.o.

Table 1. Indicators and sub indicators of CSR

\begin{tabular}{|c|c|}
\hline Indicators & Sub indicators \\
\hline Social & $\begin{array}{l}\text { Education } \\
\text { Work environment and employees } \\
\text { Culture and Art } \\
\text { Health and Safety } \\
\text { Social and Humanitarian giving }\end{array}$ \\
\hline Environment & $\begin{array}{l}\text { Ecology and Environment Protection } \\
\text { Recycling } \\
\text { Sustainable management of natural } \\
\text { resources } \\
\text { The use of clean energy } \\
\text { Prevention of pollution }\end{array}$ \\
\hline Economic & $\begin{array}{l}\text { Preserving profitability and profit } \\
\text { Contribution to economic development }\end{array}$ \\
\hline
\end{tabular}

designated as $A_{2}$ and Vip mobile d.o.o. designated as $A_{3}$ ) that in their operations apply concepts of CSR.

Based on investigated literature and CSR reports of mentioned companies, the authors propose the following model of indicators and sub indicators of telecommunications sector of CSR that will be relevant for research and ranking of companies according to the CSR (Table 1).

\section{THE COMPUTATIONAL PROCEDURE OF THE SWARA METHOD}

The new Step-wise Weight Assessment Ratio Analysis (SWARA) technique was proposed by Kersuliene et al. (2010). Although it is a newly proposed method, it was used to solve many problems such as a rational dispute resolution (Kersuliene et al., 2010), the selection of packaging design (Stanujkic et al., 2015), an architect selection (Kersuliene \& Turskis, 2011), the design of products (Zolfani et al., 2013), a machine tool selection (Aghdaie et al., 2013), the prioritizing of the sustainability assessment indicators of the energy system (Zolfani \& Saparauskas, 2013) and a personnel selection (Zolfani \& Banihashemi, 2014).

The process of determining the relative weights of criteria using SWARA method can accurately be shown by using the following steps:

Step 1. The criteria are sorted in descending order based on their expected significances.

Step 2. Starting from the second criterion, the respondent expresses the relative 
importance of criterion $j$ in relation to the previous $(j-1)$ criterion, for each particular criterion. According to Kersuliene et al. (2010), this ratio is called the Comparative importance of average value, $s_{j}$.

Step 3. Determine the coefficient $k_{j}$ as follows:

$k_{j}=\left\{\begin{array}{cc}1 & j=1 \\ s_{j}+1 & j>1\end{array}\right.$.

Step 4. Determine the recalculated weight $q_{j}$ as follows:

$q_{j}=\left\{\begin{array}{cc}1 & j=1 \\ \frac{q_{j-1}}{k_{j}} & j>1 .\end{array}\right.$

Step 5. The relative weights of the evaluation criteria are determined as follows:

$w_{j}=\frac{q_{j}}{\sum_{k=1}^{n} q_{k}}$,

where $w_{j}$ denotes the relative weight of criterion $j$.

\section{THE COMPUTATIONAL PROCEDURE OF THE ARAS METHOD}

The ARAS method was proposed by Zavadskas and Turskis (2010). Despite the fact that the ARAS method is a relatively new method, the ARAS method until now has been used for solving decision making problems in diffrent areas, such as those related to construction (Lazauskas et al., 2015; Medineckiene et al., 2015), selection of the chief accountant (Keršulienè \&
Turskis, 2014), waste dump site selection (Shariati et al., 2014), ranking of financial institutions (Reza \& Majid, 2013) and so on.

The usability and efficiency of the ARAS methods have also been confirmed by its extensions, such as ARAS-G method (Turskis \& Zavadskas, 2010) which enable the use of grey numbers, and extension proposed with the aim to enable the use of interval-valued triangular fuzzy numbers (Stanujkic, 2015).

The process of solving decision making problems using ARAS method, similarly to the other methods of MCDM, starts with forming the decision matrix and determining weights of criteria. After these initial steps, the remaining part of solving MCDM problem using ARAS method can be precisely expressed using the following steps:

Step 1. Determine the optimal performance rating for each criterion. In this step the decision maker sets the optimal performance rating for each criterion. If the decision maker does not have a preferences, the optimal performance ratings are calculated as:

$x_{0 j}=\left\{\begin{array}{ll}\max _{i} x_{i j} ; & j \in \Omega_{\max } \\ \min _{i} x_{i j} ; & j \in \Omega_{\min }\end{array}\right.$,

where denotes the optimal performance rating of $j$-th criterion, $\Omega_{\max }$ denotes the benefit criteria, i.e. the higher the values are, the better it is; and $\Omega_{\text {min }}$ denotes the set of cost criteria, i.e. the lower the values are, the better it is.

Step 2. Calculate the normalized decision matrix. The normalized performance ratings 
are calculated using the following formula: formula:

$r_{i j}=\left\{\begin{array}{ll}\frac{x_{i j}}{\sum_{i=0}^{m} x_{i j}} ; & j \in \Omega_{\max } \\ \frac{1 / x_{i j}}{\sum_{i=0}^{m} 1 / x_{i j}} ; & j \in \Omega_{\min }\end{array}\right.$,

where $r_{i j}$ denotes the normalized performance rating of $i$-th alternative in relation to the $j$-th criterion, $i=0,1, \ldots, m$.

Step 3. Calculate the weighted normalized decision matrix. The weighted normalized performance ratings are calculated using the following formula:

$v_{i j}=w_{j} r_{i j}$,

where $v_{i j}$ denotes the weighted normalized performance rating of $i$-th alternative in relation to the $j$-th criterion, $i=0,1, \ldots, m$.

Step 4. Calculate the overall performance rating, for each alternative. The overall performance ratings can be calculated using the following formula:

$S_{i}=\sum_{j=1}^{n} v_{i j}$,

where $S_{i}$ denotes the overall performance rating of $i$-th alternative, $i=0,1, \ldots, m$.

Step 5. Calculate the degree of utility for each alternative. When evaluating alternatives, it is not only important to determine the best ranked alternative. It is also important to determine relative performances of considered alternatives, in relation to the optimal alternative. For this purpose the degree of utility is used, and it can be calculated using the following

$$
Q_{i}=\frac{S_{i}}{S_{0}},
$$

where $Q_{i}$ denotes the degree of utility of $i$-th alternative, and $S_{0}$ is the overall performance index of optimal alternative, $i=1,2, \ldots, m$.

Step 6. Rank alternatives and/or select the most efficient one. The considered alternatives are ranked by ascending $Q_{i}$, i.e. the alternative with the largest value of $Q_{i}$ is the best placed.

\section{A FRAMEWORK FOR RANKING COMPANIES ACCORDING TO THE CSR INDICATORS}

A framework for evaluating companies according to the CSR indicators, based on the application of the SWARA and the ARAS methods can be accurately demonstrated using the following steps.

Step 1. Determining the significance of criteria or sub-criteria. In this step, the decision-maker, using the SWARA method, determines the significance of criteria, as well as their sub-criteria. Finally, the resulting weights of sub-criteria that will be used for evaluation are determined using the following formula:

$w_{i j}^{r}=\frac{w_{i} w_{i j}}{\sum_{i, j} w_{i} w_{i j}}$,

where $i$ denotes criteria, $j$ denotes sub criteria.

Step 2. Evaluation of alternatives in relation to the selected set of criteria. In this 
step, using the mark in the interval of 1-5 decision maker evaluates.

Step 3. Ranking and selection of the most appropriate company. In this step, using ARAS method, determining the performance of alternatives, and performs the selection of the company which in its business apply CSR.

Table 2. The significance of criteria

\begin{tabular}{|c|c|c|c|c|c|c|}
\hline & Criteria & Designation & $s_{j}$ & $k_{j}$ & $q_{j}$ & $w_{j}$ \\
\hline$C_{1}$ & Social & & & 1 & 1 & 0.381 \\
\hline$C_{2}$ & Environmental & & 0.11 & 1.11 & 0.901 & 0.344 \\
\hline$C_{3}$ & Economic & & 0.25 & 1.25 & $\begin{array}{l}0.721 \\
2.622\end{array}$ & $\begin{array}{l}0.275 \\
1.000\end{array}$ \\
\hline
\end{tabular}

Table 3. Significance of sub-criteria for criteria Social

\begin{tabular}{llccccc}
\hline & Criteria & Designation & $s_{j}$ & $k_{j}$ & $q_{j}$ & $w_{1 j}$ \\
\hline$C_{11}$ & Education & ED & & 1 & 1 & 0.317 \\
$C_{12}$ & Work environment and employees & WEE & 0.15 & 1.15 & 0.870 & 0.276 \\
$C_{13}$ & Culture and Art & CA & 0.25 & 1.25 & 0.696 & 0.221 \\
$C_{14}$ & Health and Safety & HS & 0.19 & 1.19 & 0.585 & 0.186 \\
$C_{15}$ & Social and Humanitarian giving & SHG & 0.29 & 1.29 & 0.453 & 0.144 \\
& & & & & 3.150 & 1.000 \\
\hline
\end{tabular}

Table 4. Significance of sub-criteria for criteria Environmental

\begin{tabular}{llccccc}
\hline & Criteria & Designation & $s_{j}$ & \multicolumn{1}{c}{$k_{j}$} & $q_{j}$ & $w_{2 j}$ \\
\hline$C_{21}$ & Ecology and Environment Protection & EEP & & 1 & 1 & 0.368 \\
$C_{22}$ & Recycling & REC & 0.09 & 1.09 & 0.917 & 0.338 \\
$C_{23}$ & Sustainable management of natural resources & SMNR & 0.15 & 1.15 & .798 & 0.294 \\
$C_{24}$ & The use of clean energy & UCE & 0.25 & 1.25 & 0.638 & 0.235 \\
$C_{25}$ & Prevention of pollution & PP & 0.3 & 1.3 & 0.491 & 0.181 \\
& & & & & 2.715 & 1.000 \\
\hline
\end{tabular}

Table 5. Significance of sub-criteria for criteria Economic

\begin{tabular}{llccccc}
\hline & Criteria & Designation & $s_{j}$ & $k_{j}$ & $q_{j}$ & $\mathrm{w}_{3 \mathrm{j}}$ \\
\hline$C_{31}$ & Preserving profitability and profit & PPP & & 1 & 1 & 0.600 \\
$C_{32}$ & Contribution to economic development & CED & \multirow{2}{*}{0.5} & 1.5 & 0.667 & 0.400 \\
& & & & & 1.667 & 1.000 \\
\hline
\end{tabular}

Table 6. Resulting weights of sub-criteria

\begin{tabular}{|c|c|c|c|c|c|c|c|c|c|c|c|c|}
\hline \multirow{4}{*}{$w_{i}$} & \multicolumn{5}{|c|}{$\begin{array}{c}C_{1} \\
\text { Social } \\
\end{array}$} & \multicolumn{5}{|c|}{$\begin{array}{c}C_{2} \\
\text { Environmental }\end{array}$} & \multirow{2}{*}{\multicolumn{2}{|c|}{$\begin{array}{c}C_{3} \\
\text { Economic } \\
0.274\end{array}$}} \\
\hline & & & 0.381 & & & & & 0.344 & & & & \\
\hline & I & II & III & IV & V & I & II & III & IV & V & I & II \\
\hline & ED & WEE & $\mathrm{CA}$ & HS & SHG & EEP & REC & SMNR & UCE & PP & PPP & CED \\
\hline$w_{i j}$ & 0.317 & 0.276 & 0.220 & 0.185 & 0.143 & 0.368 & 0.337 & 0.293 & 0.235 & 0.180 & 0.600 & 0.400 \\
\hline$w_{i j}^{r}$ & 0.101 & 0.088 & 0.070 & 0.059 & 0.046 & 0.106 & 0.097 & 0.084 & 0.068 & 0.052 & 0.138 & 0.092 \\
\hline
\end{tabular}


obtained from the formula (9), are shown in table 6.

Ratings of three companies in relation to the selected set of criteria are shown in table 7. telecommunication sector. According to the information available to authors, combination of SWARA-ARAS method for decision making has not been used to rank companies according to the CSR indicators.

Table 7. Ratings of evaluated companies (in relation to the selected set of criteria)

\begin{tabular}{|c|c|c|c|c|c|c|c|c|c|c|c|c|}
\hline \multirow[b]{2}{*}{$w_{i j}^{r}$} & \multicolumn{5}{|c|}{$\begin{array}{c}C_{1} \\
\text { Social }\end{array}$} & \multicolumn{5}{|c|}{$\begin{array}{c}C_{2} \\
\text { Environmental } \\
\end{array}$} & \multicolumn{2}{|c|}{$\begin{array}{c}C_{3} \\
\text { Economic }\end{array}$} \\
\hline & 0.101 & 0.088 & 0.070 & 0.059 & 0.046 & 0.106 & 0.097 & 0.084 & 0.068 & 0.052 & 0.138 & 0.092 \\
\hline & I & II & III & IV & $\mathrm{V}$ & I & II & III & IV & $\mathrm{V}$ & I & II \\
\hline & ED & WEE & CA & HS & SHG & EEP & REC & SMNR & UCE & PP & PPP & CED \\
\hline$A_{1}$ & 4 & 3 & 3 & 4 & 4 & 4 & 5 & 4 & 3 & 3 & 4 & 4 \\
\hline$A_{2}$ & 5 & 4 & 3 & 4 & 5 & 3 & 4 & 5 & 4 & 3 & 4 & 5 \\
\hline$A_{3}$ & 5 & 4 & 4 & 4 & 4 & 4 & 4 & 5 & 4 & 4 & 4 & 4 \\
\hline
\end{tabular}

Weighted normalized decision matrix is shown in Table 8.
SWARA method is used to evaluate weights of indicators and sub-indicators, then ARAS

Table 8. Weighted normalized decision matrix

\begin{tabular}{|c|c|c|c|c|c|c|c|c|c|c|c|c|}
\hline \multirow[b]{2}{*}{$w_{i j}^{r}$} & \multicolumn{5}{|c|}{$\begin{array}{c}C_{1} \\
\text { Social }\end{array}$} & \multicolumn{5}{|c|}{$\begin{array}{c}C_{2} \\
\text { Environmental }\end{array}$} & \multicolumn{2}{|c|}{$\begin{array}{c}C_{3} \\
\text { Economic } \\
\end{array}$} \\
\hline & 0.101 & 0.088 & 0.070 & 0.059 & 0.046 & 0.106 & 0.097 & 0.084 & 0.068 & 0.052 & 0.138 & 0.092 \\
\hline & I & II & III & IV & V & I & II & III & IV & V & I & II \\
\hline & ED & WEE & CA & HS & SHG & EEP & REC & SMNR & UCE & PP & PPP & CED \\
\hline$A_{0}$ & 0.036 & 0.032 & 0.028 & 0.020 & 0.018 & 0.038 & 0.037 & 0.030 & 0.025 & 0.021 & 0.046 & 0.035 \\
\hline$A_{1}$ & 0.029 & 0.024 & 0.021 & 0.020 & 0.014 & 0.038 & 0.037 & 0.024 & 0.018 & 0.016 & 0.046 & 0.028 \\
\hline$A_{2}$ & 0.036 & 0.032 & 0.021 & 0.020 & 0.018 & 0.029 & 0.030 & 0.030 & 0.025 & 0.016 & 0.046 & 0.035 \\
\hline$A_{3}$ & 0.036 & 0.032 & 0.028 & 0.020 & 0.014 & 0.038 & 0.030 & 0.030 & 0.025 & 0.021 & 0.046 & 0.028 \\
\hline
\end{tabular}

Final performances and ranking of method is used for ranking alternatives in our evaluated alternatives are shown in Table 9.

Table 9. Results of ranking of alternatives

\begin{tabular}{cccc}
\hline & $S_{i}$ & $Q_{i}$ & Rank \\
\hline$A_{0}$ & 0.366 & & \\
$A_{1}$ & 0.316 & 0.066 & 3 \\
$A_{2}$ & 0.337 & 0.082 & 1 \\
$A_{3}$ & 0.348 & 0.082 & 1 \\
\hline
\end{tabular}

\section{CONCLUSION}

Presently, companies are faced with the demands and efforts in terms of action in the field of corporate social responsibility. In this paper authors are proposing a framework for ranking companies according to CSR in example companies. From the presented framework, as well as illustration example, we can conclude that SWARA-ARAS method is easily applicable, adaptive and it can be used to rank companies according to the CSR indicators. According to given framework and methodology Company 2 and Company 3 is ranked as best in terms of CSR.

\section{References}

Aghdaie, M.H., Zolfani, S.H., \& Zavadskas, E.K. (2013). Decision making in machine tool selection: An integrated 


\title{
РАНГИРАҢЕ ПРЕДУЗЕЋА ПРЕМА ИНДИКАТОРИМА ДРУШТВЕНЕ ОДГОВОРНОСТИ НА ОСНОВУ "SWARA" И “ARAS" МЕТОДА
}

\author{
Дарјан Карабашевић, Џејн Паунковић и Драгиша Станујкић
}

\section{Извод}

Привреда и компаније препознају значај имплементације стратегије корпоративне друштвене одговорности са циљем поправљања имиџа и одговорности компанија према друштву и заједницама у којима делују. Мултинационалне компаније у својим свакодневним активностима и операцијама обраћају више пажње на одрживе моделе корпоративне друштвене одговорности. Фокус овог рада је идентификација индикатора корпоративне друштвене одговорности и рангирање компаније према тим индикаторима. Предложени оквир за вредновање и рангирање се заснива на "SWARA" и “ARAS" методама. Употребљивост и ефикасност предложеног оквира је приказане на илустративном примеру.

Кључне речи: корпоративна друштвена одговорност, CSR индикатори, CSR димензије, SWARA, ARAS, MCDM

approach with SWARA and COPRAS-G methods. Inzinerine Ekonomika Engineering Economics, 24 (1), 5-17.

Berger, I.E., Cunningham, P.H., \& Drumwright, M.E. (2007). Mainstreaming corporate social responsibility: Developing markets for virtue. California Management Review, 49 (4), 132-160.

Brans, J.P., \& Vincke, P. (1985). A preference ranking organization method: The PROMETHEE method for MCDM, Management Science, 31 (6), 647-656.

Carroll, A.B. (1999). Corporate social responsibility: Evolution of a definitional construct. Business and Society Review, 38 (3), 268-295.

Chen, S., Fan, J. (2011). Measuring Corporate Social Responsibility Based on a Fuzzy Analytical Hierarchy Process. I.J. Computer Network and Information Security, 5, 13-22.

Commission of the European
Communities (2002), Corporate Social Responsibility, Main Issue, Brussels.

Dahlsrud, A. (2006). How Corporate Social Responsibility is Defined: an Analysis of 37 Definitions. Corporate Social Responsibility and Environmental Management, 15 (1), 1-13.

Dyllick, T., \& Hockerts, K. (2002). Beyond the Business Case for Corporate Sustainability. Business Strategy and the Environment, 11, 130-41.

Ebrahimi, E., Zohrei, S., \& Emadi, M. (2014). Assessing the Corporate Social Responsibility Using Shannon's Entropy and VIKOR Methods. Global Journal of Management Studies and Researches, 1 (1), 54-61.

European Comission (2010). Environment 2010: Our future, Our choice. 6th EU Environment action programme.

European Union (2007). Treaty of Lisbon, art. 3 . 
Farooq, O., Payaud, M., Merunka, D., \& Valette-Florence, P. (2014). The Impact of Corporate Social Responsibility on Organizational Commitment: Exploring Multiple Mediation Mechanisms. Journal of Business Ethics, 125, 563-580.

Graafland, J.J., Eijffinger, S.C.W., \& Smid, H. (2004). Benchmarking of Corporate Social Responsibility: Methodological Problems and Robustness. Journal of Business Ethics, 53 (1-2), 137152.

Graves, S.B., Waddock, S.A., \& Kelly, J. (2002). 100 Best Corporate Citizens. Business Ethics, 11 (2), 8-13.

$\mathrm{Hu}, \mathrm{J} . \mathrm{W}-\mathrm{S} ., \mathrm{Hu}, \mathrm{Y}-\mathrm{C}$. , \& Bein, H-C. (2011). Constructing a Corporate Social Responsibility Fund Using Fuzzy Multiple Criteria Decision Making. International Journal of Fuzzy Systems, 13(3), 195-205.

Hwang, C.L., \& Yoon, K. (1981). Multiple attribute decision making: methods and applications; a state-of-the-art survey. 1st edition. Berlin: Springer.

Kersuliene, V., \& Turskis, Z. (2011). Integrated fuzzy multiple criteria decision making model for architect selection. Technological and Economic Development of Economy, 17 (4), 645-666.

Keršulienė, V., \& Turskis, Z. (2014). An integrated multi-criteria group decision making process: selection of the chief accountant. Procedia - Social and Behavioral Sciences, 110, 897-904.

Kersuliene, V., Zavadskas, E.K., \& Turskis, Z. (2010). Selection of rational dispute resolution method by applying new step - wise weight assessment ratio analysis (SWARA). Journal of Business Economics and Management, 11 (2), 243-258.

Kotler, P., \& Lee, N. (2005). Corporate Social Responsibility: Doing the Most Good for Your Company and Your Cause. John
Wiley \& Sons, Inc., Hoboken, New Jersey.

Krut, R., \& Munis, K. (1998). Sustainable Industrial Development: Benchmarking Environmental Policies and Reports. Greener Management International, 21, 8898.

Lazauskas, M., Kutut, V., \& Zavadskas, E.K. (2015). Multicriteria assessment of unfinished construction projects. Građevinar, 67 (4), 319-328.

Medineckienea, M., Zavadskas, E.K., Björka, F., \& Turskis, Z. (2015). Multicriteria decision-making system for sustainable building assessment/certification. Archives of Civil and Mechanical Engineering, 15 (1), 11-18.

Opricovic, S. (1998). Multi-criteria optimization of civil engineering systems, Faculty of Civil Engineering, University of Belgrade.

Paunkovic, J. (2014). Educational Programs for Sustainable Societies Using Cross-Cultural Management Method. Global Sustainable Communities Handbook: Green Design Technologies and Economics, 387404.

Pérez, A., \& Bosque, I.R. (2013). Measuring CSR Image: Three Studies to Develop and to Validate a Reliable Measurement Tool. Journal of Business Ethics, 118, 265-286.

Reza, S., \& Majid, A. (2013). Ranking Financial Institutions Based on of Trust in online banking Using ARAS and ANP Method. International Research Journal of Applied and Basic Sciences, 6 (4), 415-423.

RobecoSAM AG (2014). The sustainability Yearbook 2014. URL: h t t p : / / w w w. s u s t a i n a bility indices.com/images/RobecoSAM_Sustainab ility_Yearbook_2014_Low-Res.pdf (25.02.2015).

Shariati, S., Yazdani-Chamzini, A., 
Salsani, A., \& Tamosaitiene, J. (2014). Proposing a New Model for Waste Dump Site Selection: Case Study of Ayerma Phosphate Mine. Inzinerine EkonomikaEngineering Economics, 25 (4), 410-419.

Sharma, S., \& Ruud, A. (2003). On the path to sustainability: integrating social dimensions into the research and practice of environmental management. Business Strategy and the Environment, 12, 205-214.

Shrivastava, P. (1995). The role of corporations in achieving ecological sustainability. Academy of Management Review, 20 (4), 936-960.

Stanujkic, D. (2015). Extension of the ARAS Method for Decision-Making Problems with Interval-Valued Triangular Fuzzy Numbers. Informatica, 26(2), 335355.

Stanujkic. D., Karabasevic, D., \& Zavadskas, E.K. (2015). A framework for the selection of a packaging design based on the SWARA method. Inzinerine Ekonomika Engineering Economics, 26 (2), 181-187.

Tafti, S.F., Hosseini, S.F., \& Emami, S.A. (2012). Assessment the Corporate Social Responsibility according to Islamic values (Case study: Sarmayeh Bank). Procedia Social and Behavioral Sciences, 58, 1139-1148.

Turker, D. (2009). Measuring Corporate Social Responsibility: A Scale Development Study. Journal of Business Ethics, 85, 411427.

Turskis, Z., \& Zavadskas, E.K. (2010). A novel method for Multiple Criteria Analysis: Grey Additive Ratio Assessment (ARAS-G) method. Informatica, 21 (4), 597-610.

Uddin, M.B., Hassan, R.M. \& Tarique, K.M. (2008). Three Dimensional Aspects of Corporate Social Responsibility. Daffodil International University Journal of Business and Economics, 3 (1), 199-212.
Waldman, D.A., Siegel, D.S., \& Javidan, M. (2006). Components of CEO Transformational Leadership and Corporate Social Responsibility. Journal of Management Studies, 43 (8), 1703-1725.

Zavadskas, E.K., \& Turskis, Z. (2010). A new additive ratio assessment (ARAS) method in multicriteria decision-making. Technological and Economic Development of Economy, 16 (2), 159-172.

Zolfani, S.H., \& Banihashemi, S.S.A. (2014). Personnel selection based on a novel model of game theory and MCDM approaches. in Proc. of 8th International Scientific Conference "Business and Management 2014", 15-16 May 2014, Vilnius, Lithuania, 191-198.

Zolfani, S.H., \& Saparauskas, J. (2013). New Application of SWARA Method in Prioritizing Sustainability Assessment Indicators of Energy System. Engineering Economics, 24 (5), 408-414.

Zolfani, S.H., Zavadskas, E.K., \& Turskis, Z. (2013). Design of products with both International and Local perspectives based on Yin-Yang balance theory and SWARA method. Ekonomska istraživanjaEconomic Research, 26 (2), 153-166. 